\title{
PRASASTI SINGKAT DARI EMPAT BUAH MAKAM ISLAM \\ DAN SEBUAH GUA DI DAERAH TUBAN
}

\author{
Oleh: M.M. Sukarto K. Atmodjo
}

\section{l)andanggula}

Sora saru ing sarengat Nabi, ing Cêbolek padusunan Tuban,

kang dadi lok lalakone,

ginêrêy ginarumung,

dening para ngalim pasisir,

aja angrusak sarak,

duraka ing ratu,

pan ratu wênang aniksa,

wus minangka badal sang nayakeng bumi,

babaya ing ubaya.

Soebardi: The Book of Cabolek, Bibliotheca Indonesica 10,

The Hague, 1975, hlm. 67.

Antara tanggal 19-28 September 1981 saya mendapat kesempatan mengunjungi beberapa obyek sejarah dan purbakala di daerah Kabupaten Tuban. Obyek itu berupa arca-arca purba agama Hindu, prasasti, gua dan beberapa buah makam Islam. Sebuah benda purbakala yang menarik perhatian yaitu prasasti batu di desa Bandungreja, Kec. Plumpang, Kab. Tuban. Prasasti itu berjumlah dua buah dan terletak kira-kira 400 meter di sebelah utara alìran Bêngawan Sala. Keduanya bertarikh 1277 Saka dan menyebut perkataan hakuți Tuban. Karena itu prasasti Bandungrêja saya sebut prasasti Tuban I dan Tuban II. Uraian selengkapnya telah dimuat di dalam karangan saya berjudul 'Sedikit Tentang Nama Kota Tuban Dan Lamongan' sewaktu diselenggarakan pekan ceramah Kegiatan Ilmiah Dalam Rangka Sumpah Pemuda Dan Lustrum V.I Fakultas Sastra Dan Kebudayaan Universitas Gadjah Mada, Yogyakarta pada tanggal 24-25 Oktober 1980. ${ }^{2}$

Kecuali itu di beberapa tempat juga masih terdapat prasasti (tulisan) singkat yang perlu diteliti lebih lanjut. Tulisan itu dipahat di atas papan kayu atau nisan batu menggunakan huruf Jawa dan Arab. ${ }^{3}$

Karena saya tidak menguasai masalah agama dan kebutlayaan Isläm (bidang Islamologi) maka uraian di bawah ini hanyalah menyangkut prasasti yarig menggunakan huruf Jawa. Itu pun saya harus mengakui tidak sang- 
igup membaca selengkapnya karena tulisan agak kabur dan sulit mem banding huruf-hurufnya berdasarkan segi paleografi. ${ }^{4}$ Ini disebabkan pra. sasti hanya terdiri dari sebaris dua baris kalimat dan tidak semua huruf (aksara) dicantumkan (diwakili).

Karena saya khawatir prasasti itu pada suatu waktu akan aus dan lenyap, saya memberanikan diri menulis karangan singkat ini. Mudahmudahan usaha ini membangkitkan semangat sarjana lainnya yang jauh lebih arif dan mengetahui seluk-beluk masalah tersebut. Harapan ini terutama saya tujukan kepada para sarjana Epigrafi dan Islamologi dari Pusat Penelitian Arkeologi Nasional di Jakarta. Setidak-tidaknya semua prasasti atau tulisan singkat tersebut di atas dicatat atau didokumentir secara cermat sehingga apabila lapuk di kemudian hari, paling tidak telah tersedia sebuah dokumen yang memadai baik berupa foto, faksimil, abklats (acuan kertas) dan lain-lainnya.

Agar masalahnya lebih jelas baiklah saya uraikan prasasti singkat tersebut beserta beberapa buah gambar (faksimil) yang diperlukan sebagai berikut:

\section{Makam Sunan Bonang.}

Makam Sunan Bonang terletak di tengah-tengah kota Tuban. Tepatnya di desa Kutareja, Kec. Tuban Kota atau di sebelah barat alunalun kota. Di dalam kompleks makam terdapat beberapa buah prasasti singkat. Dua buah di antaranya yang menarik perhatian yaitu:

a. Pintu-gerbang pertama.

Di bagian atas pintu-gerbang pertama terpahat sebaris tulisan dengan huruf Jawa berbunyi 'rasa tunggal pandita wahdat'. Kalimat itu sesuai dengan nama Sunan Bonang yang juga disebut Sunan Wahdat di dalam Suluk Wujil. ${ }^{5}$ Oleh Dr. Poerbatjaraka nama itu diterjemahkan 'Den Heer Celibatair' ${ }^{6}$

Kalimat 'rasa tunggal pandita wahdat' merupakan sebuah kronogram (candra-sêngkala) yang melambıngkan nilai angka tertentu yaitu: rasa (rasa) bernilai $6,7^{7}$ tunggal (tunggal) 1, pandita (pendeta) 7 dan wahdat (selibat) 1 . Angka itu apabila dibaca dari kanan,ke kiri atau dibalik menjadi 1716 AJ. ${ }^{8:}$ Jadi kira-kira bertepat an dengan tahun $1789 \mathrm{AD} .^{9}$

Prasasti itu pernah dimuat di dalam makalah Sdr. Umiati Rochmat berjudul 'Sekitar Tarikh Pada Gapura Makam Sunan Bonang' pada Pertemuan Ilmiah Arkeologi II di Jakarta tahun 1980, tetapi hanya dibaca 'rasa tunggal pandita ....'. Pengamatan saya lebih lanjut membuktikan bahwa perkataan terakhir harus dibaca wahdat. Perkataan wahdat untuk Sunan Bonang memang perlu diteliti lebih lanjut karena selain berarti 'selibat' (tidak beristri) mungkin juga berarti 'seseorang yang taat melakukan ibadah agama'.

\section{b. Alas dinding makam.}

Sebilah kayu jati yang digunakan alas dinding (gêbyog) makam Sunan Bonang di sebelah kanan tangga atau pintu masuk dipahat dengan tulisan Jawa Baru yang sebagian sudah aus. Menurut ke- 
terangan jurukunci beberapa orang telah mencoba membaca tulisan itu, tetapi hasilnya belum memuaskan.

Prasasti singkat itu mungkin juga sebuah kronogram dan apabila tidak salah berbunyi 'janma wyahana kayuning sawit jagat'. Perkataan pertama agak meragukan karena huruf ja kelihatan seperti tanda taling dan huruf kedua berlainan dengan na pada perkataan kayuning. Kalimat itu lebih-kurang berarti 'hakekat manusia merupakan batang kayu (pohon) dunia'. Penggunaan perkataan kayu sesuai dengan bahan yang digunakan (alas kayu) tetapi mungkin juga melambangkan kayun (kehendak, maksud). Sawit jagat mengandung pengertian kayu jati dan juga melambangkan sejatining urip (hakekat dan kenyataan hidup).

Perkataan janma (manusia) bernilai 1, wyahana (hakekat, keadaan) 1, kayu (kayu, pohon) 6 dan sawit jagat (pohon, awal dunia) 1. Dengan demikian kronogram itu melambangkan angka 1161 atau tahun 1611 AJ. Jadi kira-kira bertepatan dengan tahun 1687 AD. Bolehjadi angka-tahun itu memperingati pembangunan atau perbaikan makam (cungkup) Sunan Bonang yang dianggap sebagai pohon dunia yang baik.

Perlu ditambahkan di sini bahwa di dalam kompleks makam Sunan Bonang masih banyak terdapat nisan batu bertulis Jawa dan Arab yang perlu diteliti lebih lanjut sebelum punah karena lapuk. Menarik perhatian sebuah nisan (Jawa maesan) ${ }^{10}$ dipahat dengan tulisan Jawa berbunyi Sundari (Sunhari) dan deretan angka 7371. Jelas yang dimaksud tahun 1737 AJ. Tahun itu bertepatan dengan tarikh 1810 AD. Tetapi pembalikan angka tersebut selain mungkin pengaruh. tulisan Arab yang harus dibaca dari kanan ke kiri juga berhubungan dengan cara penulisan kronogram yang harus dibalik membacanya dari kanan ke kiri.

Sebuah nisan lainnya dipahat dengan angka 8 (?) 071 (nisan sisi utara) dan nama Saramênggala (nisan sisi selatan). Jadi yang dimaksud Saramenggala (Suramenggala?) ${ }^{11}$ meninggal pada tahun 1708 AJ atau kira-kira bertepatan dengan tahun $1791 \mathrm{AD}$.

Sebuah nisan yang cukup tua di samping cungkup Sunan Bonang dipahat dengan tulisan Jawa yang indah sebanyak empat baris. Sayang sekali sebagian huruf telah aus dan kronogram yang masih terbaca berbunyi . . sêmbahe ratu dan melambangkan tahun 12 . . . yaitu tahun Hijriah (AH). Perkataan sêmbah bernilai 2 (menyeumbang dengan dua buah tangan) dan ratu (raja) bernilai 1 .

\section{Makam Ranggalawe}

Makam Ranggalawe terletak di tengah kota Tuban, tepatnya di dukuh Kajongan, desa Sidamulya, Kec. Tuban Kota. Di dalam kompleks makam terdapat ratusan makam penduduk dan beberapa buah cungkup. Sebuah cungkup yang relatif besar berisi makam beberapa orang tokoh penting yang berjajar dari barat ke arah timur. Menurut keterangan R. Soeparmo di dalam bukunya 'Tjatatan Sedjarah $700 \mathrm{Ta}$ - 
hoen Toeban' (percetakan Sroeni, Toeban 1972) makam tersebut berisi makam beberapa orang tokoh penting, yaitu:
a. Arya Lena,
b. Nyai Agêng Arya Teja,
c. Nyai Agêng Bata Lara,
d. Nyai Agêng Gunsiah,
e. Nyai Agêng Manila,
f. Arya Balabar,
g. Ranggalawe (tanpa nisan),
h. Arya Lawe,
i. Arya Wênang,
j. Rara Kuța,
k. Arya Teja,
1. Arya Dikara.

Tetapi anehnya jurukunci makam sendiri hanya mengetahui beberapa buah makam, yaitu: makam Arya Lena, Nyai Agêng Manila, Ranggalawe, Rara Kuța (saudara Sunan Bonang tunggal bapa), Arya Teja dan Arya Dikara. Pertanyaan apakah Ranggalawe juga dimakamkan di tempat itu masih belum terjawab karena Ranggalawe menurut hemat saya bukannya seorang muslim. Ia seorang pemeluk agama Hindu.

Di dalam kompleks makam (luar cungkup) terdapat beberapa buah nisan batu yang dipahat dengan huruf Jawa, Arab dan juga angka tahun. Sebuah nisan batu terletak di sebelah barat cungkup Ranggalawe dipahat dengan huruf Jawa berbunyi Baginda Purwarểa dan tahun meninggalnya (wafat) 1798 AJ. Tahun itu bertepatan dengan 1869 AD. Jadi beberapa puluh tahun setelah selesai perang Dipanegara.

Menurut keterangan seorang penduduk Baginda Purwareja juga seorang pengikut Pangeran Dipanegara dan kalau berperang hanya membawa bekal gêrit, yaitu nasi ketan kering. Apabila gêrit dicampur dengan air panas akan mengembang (membesar) dan akhirnya dapat dimakan.

Bentuk tulisan baginda sangat menarik, lebih-lebih huruf ga yang digayakan (setilir) dan menyerupai kaligrafi tulisan Jawa (lihat faksimil). Perkataan wafat ditulis dengan huruf wa dengan tiga buah titik di atasnya dan huruf ha dengan sebuah titik di atasnya. Selain itu sebuah makam yang dikenal penduduk sebagai makam mBah Kaji Sultan dari Madura juga sangat menarik karena nisannya diukir dengan hiasan serban (utêr) $?^{2}$ Bentuk nisan demikian juga terdapat di pulau Madura.

\section{Makam Sunan Bejagung.}

Makam Sunan. Bêjagung terletak di desa Bêjagung, Kec. Sêmanding, Kab. Tuban. Di dalam sebuah cungkup yang sudah dipugar oleh seseorang di Tuban terdapat makam Sunan Bejagung, istrinya dari Campa dan juga anaknya. Menurut keterangan jurukunci nama Bêja- 
gung berasal dari maja agung. Diceritakan pada waktu tentara Maja pahit datang ke Tuban hendak menaklukkan kelompok orang-orang Islam mereka bertemu dengan seorang tua di tengah tegalan. Karena dahaga tentara Majapahit minta air kepada orang tua tersebut dan diberi air dengan wadah buah maja. Tetapi ketika diminum ternyata tidak habis-habisnya dan mencukupi seluruh pasukan Majapahit. Karena itulah desa tersebut dinamakan Maja Agung (buah maja besar) dan lambat-laun berubah menjadi Bejagung. Ternyata orang tua tersebut di atas Sunan Bejagung sendiri. Di sebelah selatan makam Sunan Bejagung juga terdapat sebuah sumur yang sangat dalam dan menurut cerita sumur itu dibuat oleh Sunan Bêjagung dengan menggunakan tongkatnya. ${ }^{13}$

Sebilah papan kayu bagian pintu-gerbang masuk makam Sunan Bejagung dipahat dengan sebaris tulisan yang sudah aus. Tulisan itu menggunakan huruf Jawa Baru dan berbunyi 'kang hamurwa lawang pu krayatingi' atau 'kang hamurwa lawang pun arya tingi'. Perkataan kang hamurwa lawang berarti 'yang memulai (membuat) pintu'. $\mathrm{Pu}$ Krayatingi atau Arya Tingi meninjuk nama orang. Siapa yang dimak sud(Pu Krayatingi (Karyatingi, Kriyatingi?) atau Artya Tingi kurang jelas. Apabila pembacaan di atas betul gelar pu (êmpu) berarti 'orang tua yang ahli mengukir (membuat senjata)' dan gelar arya menunjuk seorang ksatriya atau prajurit. Perkataan pun yang berhubungan dèngan nama orang hanya berarti "si"

Mengingat tulisan singkat di atas menyebut nama orang, rupa-rupanya kalimat itu bukannya sebuah kronogram. Dilihat dari segi paleografi tulisan itu berasal dari sekitar tahun 1800 Masehi.

Selain tulisan tersebut di atas /di rumah joglo yang terletak di dekat makam juga terpahat angka-tahun dan kronogram berbunyi '1728 sarira nêmbah pandịta ratu'. Kalimat sarira nêmbah panḑita ratu (badan menyembah pendeta raja) juga melambangkan angka-tahun 1728 AJ (1801 AD). Perkataan sarira (badan, tubuh), bernilai 8, nểmbah (menyembah) 2, pandita (pendeta) 7 dan ratu (raja) 1 . Karena itu diperkirakan bahwa bangunan joglo tersebut dibangun atau diperbaiki pada tahun $1801 \mathrm{AD}$.

\section{Makam Seh Ibrahim Asmara}

Makam Seh Ibrahim Asmara terletak di desa Gesikharja, Kac. Palang, Kab. Tuban. Sebuah pintu gerbang yang menghadap selatan pada bagian ambang kayu terpahat sebaris tulisan yang sebagian huruf-hurufnya sudah lapuk. Menurut keterangan jurukunci ambang pintu itu berasal dari pecahan kayu perahu dan berbunyi jung bệah kinarya lawang'. Pengamatan saya lebih lanjut menunjukkan bahwa prasasti singkat itu mungkin berbunyi 'jung pêcah kinarya lawang' (jung pecah dijadikan pintu) atau 'jung pecah kinarya rang' (jung pecah dijadikan penutup). Perkataan pertama rupa-rupanya memang berbunyi jung (perahu) meskipun tanda cecak (ng) mirip ulu (i). Perkataan kedua bukannya bêdah (tembus, pecah) tetapi pêcah (pecah), 
ketiga mungkin kinarya (dikerjakan) meskipun ya ditulis menyerupai huruf pa. Perkataan keempat mungkin lawang (pintu) atau rana (alingaling, penutup), karena huruf terakhir mirip na Jawa Kuno dan huruf sebelumnya menyerupai ra.

Pertanyaan apakah kalimat di atas juga merupakan sebuah kronogram belum dapat dijawab secara jelas. Apabila memang kronogram maka jung bernilai 4, pêcah 0 , kinarya 3 dan rana 1 . Angka itu jika dibalik menjadi 1304 AH dan kira-kira bertepatan dengan $1816 \mathrm{AD}$. Dipandang dari segi paleografi memang tulisan tersebut berasal dari sekitar abad XVII-XVIII Masehi. Mengapa tahun Hijriah, karena apabila tahun Jawa atau tahun Saka maka tulisan itu berarti berasal dari jaman Majapahit. Demikian pula perkataan terakhir lebih tepat dibaca rana dan mungkin bernilai 1 , karena lawang di dalam sêngkalan bernilai 9. Tetapi seperti telah saya terangkan di atas kalimat itu tidak harus merupakan sebuah kronogram. Mungkin juga hanya merupakan kalimat biasa seperti tulisan di makam Sunan Bejagung.

Selain tulisan tersebut di atas, bagian kayu pêngêrêt paseban di dalam kompleks makam Seh Ibrahim Asmara juga ditatah dengan sebaris tulisan berbunyi 'kang hamangun pasiban kiyahih . . . 1 . . ' (yang membangun pasiban kiyahi. .. i ....). Sayang nama kiyahi tersebut tidak terbaca karena tulisan aus. Huruf yang masih tertinggal i hanyalah tanda ulu atau suara $i$.

Perlu ditambahkan bahwa di luar makam Seh Ibrahim Asmara (Asmarakondi) juga masih terdapat beberapa buah nisan batu berangka-tahun dan juga menyebut nama orang yang dikubur di tempat itu.

\section{Gua Gembul}

Gua Gêmbul terletak di desa Jadi, Kac. Sêmanding, Kab. Tuban. Menurut cerita rakyat gua itu dahulu tempat persembunyian Sunan Kalijaga sewaktu bernama Lokajaya dan bertingkah sebagai seorang penyamun. Cerita lain mengatakan gua itu tempat berkumpul dan bermusyawarah para wali (wali sanga).

Gua Gembul merupakan gua alam sedalam beberapa meter dan terletak di tebing sebuah jurang atau pinggir sebuah lembah.

Gua Gembul mudah didatangi dengan menaiki sebuah tangga kayu setelah melewati sebuah dataran yang cukup lebar dan rindang karena banyak tumbuh pohon-pohon besar. Di depan gua terbentang aliran sebatang sungai kecil yang mengalir memanjang di daerah tandus dan berbatu kapur. Tidak jauh dari gua Gembul atau di pinggiran sungai kecil tersebut terdapat mata-air yang cukup jernih dan merupakan sumber yang sangat penting untuk penduduk di daerah sekitarnya.

Di samping gua terdapat sebilah papan kayu yang dipahat dengan dua baris tulisan Jawa Baru yang sebagian huruf-hurufnya sudah lapuk. Anehnya prasasti itu juga menyebut tanggal 7 dan tahun 1761 dengan tulisan (angka) Latin. Tidak jelas apakah 1761 tersebut merupakan tahun Jawa (AJ) atau tahun Masehi (AD). ${ }^{14}$ Tetapi karena pra- 
sasti menyebut nama bulan Mulut dan windu (siklus 8 tahun) Wawu rupa-rupanya yang dimaksud tahun $1761 \mathrm{AJ}$ dan bertepatan dengan 1833 AD. Dengan demikian sampai tahun 1982 prasasti singkat itu baru berumur 149 tahun.

Jelasnya prasasti singkat Gua Gêmbul tersebut di atas berbunyi sebagai berikut:

1. Bangdara (?) wit mas sumannasa lan malangyuda sammi tuban negara

2. hawit malem rbo tanggal ping. 7. mulut wawu. 1761. mulih garlapa (?)

Berarti lebih-kurang:

1. ... Mas Sumannasa dan Malangyuda sama-sama dari negara Tuban

2. mulai malam Rebo tanggal. 7. bulan Mulut windu Wawu. 1761. pulang ...

Perkataan pertama tidak jelas apakah berbunyi bangdara (gelar bêndara) atau hangnarawit (memulai?). Demikian pula perkataan terakhir yang saya baca garlapa masih tetap meragukan.

Mungkin yang dimaksud mulih marlapa dan berarti 'pulang lemah lunglai dan lapar', artinya setelah melakukan tapa-brata atau tirakat di dalam gua Gêmbul. Namun demikian dugaan itu hanyalah berdasarkan perkiraan belaka. Yang jelas prasasti singkat di atas menyebut nama dua orang dari negara (kota, daerah) Tuban masing-masing bernama Sumannasa ${ }^{15}$ dan Malangyuḍa.

Selain tulisan singkat tersebut di atas di dalam gua Gêmbul juga masih terlihat corat-coret tulisan lainnya yang menyebut nama orangorang tertentu. Mudah diduga bahwa nama itu merupaian nama orang yang telah berkunjung atau bertapa di gua Gembul. Sebuah tulisan menyebut nama Tirtarểja dan angka-tahun 1869 .

Demikianlah uraian singkat saya mengenai beberapa buah prasasti atau tulisan yang terdapat di dalam empat buah makam Islam dan sebuah gua di daerah Tuban. Tentu saja di tempat lain di Tuban masih ditemukan juga tulisan yang perlu diteliti lebih lanjut. Bahkan di tengahtengah kota Tuban masih terdapat dua buah yoni batu yang ditatah dengan tulisan kuno dan menyebut angka (tahun ?) 1400. Yoni batu itu dikenal oleh penduduk setempat bernama Watu Tiban. ${ }^{16}$ Juga sebuah gua yang disebut gua Suci di desa Wangun (Kac. Palang, Kab. Tuban) digores dengan beberapa buah gambar wayang, binatang, lambang kelamin lakilaki dan wanita (phallus dan vulva) dan bahkan angka-tahun 1295 \$aka. ${ }^{17}$ Pendek kata penelitian di daerah Tuban baik yang menyangkut bidang Prasejarah, Arkeologi Klasik (jaman Hindu) maupun bidang Islamologi perlu ditingkatkan. 
Gratias agamus Domino Deo nostro, marilah mengucap terima kasih kepada Tuhan Allah kita.

Amin.

\section{Catatan:}

1. Perkataan kuți di dalam bahasa Jawa Kuno berhubungan dengan wihära, yaitu tempat tinggal para pendeta (biara) Sampai sekarang di sebelah barat-daya kota Tuban $( \pm 5 \mathrm{~km})$ masih terdapat sebuah desa bernama Kuți. Di desa itu masih ditemukan sisa-sisa pondamen bangunan kuno. Demikianlah perkataan hakuţi tuban di dalam prasasti Tuban I dan Tuban II, meskipun lokasinya tidak harus sama, mungkin sekali berubah menjadi nama desa Kuti dan Kota Tuban sekarang.

2. Di dalam makalah itu saya menghubungkan nama Tuban dengan nama tumbuh-tumbuhan tuba yang digunakan untuk meracun ikan. Perkataan tuba mendapat akhiran an dan akhirnya menjadi Tuban. Dugaan itu berlandaskan kenyataan bahwa di sebelah timur kota Tuban masih terdapat nama desa Panyuran yang berasal dari perkataan nyur (nyiur). Berlainan dengan desa di sekitarnya, desa Panyuran penuh tanaman pohon kelapa. Juga di sebelah barat-laut kota Tuban masih terdapat nama desa Jenu yang berarti tuba (jênu = tuba). Etimologi rakyat mengatakan nama Tuban berasal dari watu tiban (batu jatuh) atau mêtu banyune (keluar airnya).

Selanjutnya nama kota Lamongan mungkin berasal dari nama Walambangan (Balambangan, Malambangan) yang disebut di dalam prasasti Malambangan dari jaman pemerintahan raja Jayanegara ( \pm 1316 AD). Prasasti itu ditemukan di daerah Lamongan sekarang. Perkataan Malambangan (Balambangan, Walambangan) mungkin berubah menjadi Lambangan dan akhirnya Lamongan. Penduduk mengatakan nama kota itu berasal dari perkataan lamong yang berarti gila. Perlu ditambahkan bahwa prasasti Malambangan juga menyebut pemujaan kepada dewa ikan (pamūją hyang iwak). Kenyataan sekarang menunjukkan bahwa sebagian penduduk Lamongan pantang (tabu) makan ikan lele.

Bolehjadi pantang makan ikan lele tersebut berasal dari bunyi prasasti Malambangan tersebut di atas. Sampai sekarang pun ikan dan kurakura (Jawa bulus) yang terdapat di dalam sungai gua Rengel (Kec. Rengêl, Kab. Tuban) masih dikeramatkan.

3. Tulisan Jawa dan Arab juga terdapat di makam Islam lainnya, seperti makam Tralaya (Jawa Timur), Asta Tengki (Madura) dan Selaparang (Lombok). Tulisan nisan makam Selaparang menggunakan huruf Arab 
(syahädah agama Islam) dan Jawa (angka-tahun) dalam bentuk kronogram berbunyi mesan gagawayan para yuga (nisan yang dikerjakan oleh anak keturunannya). Kalimat itu melambangkan angka 2 (mesan), 4 (gagawayan), 1 (para) dan 1 (yuga). Kalau dibalik menjadi tahun 1142 AH. Kira-kira bertepatan dengan tahun 1729 AD. Selanjutnya tentang makam Selaparang lihat karangan Stutterheim 'Een Inscriptie van Lombok', Djawa, 17e Jaargang, 1937, hlm. $309-310$. Juga karangan pendek M.M. Sukarto 'Makam Islam Purba Selaparang', di dalam Aneka Purbakala, Brosur no. 6 - 7, th. 1974-1975, hlm. 8-12 (Kantor Cabang II, LPPN, Gianyar).

4. Paleografi ialah ilmu yang mempelajari bentuk tulisan kuno. Dengan demikian prasasti yang tidak berangka-tahun masih mungkin diketahui jamannya menurut bentuk huruf-hurufnya. Perkiraan itu bertambah meyakinkan apabila didukung data lainnya (langgam bahasa, bangunan candi dan temuan serta lainnya).

5. Lihat Poerbatjaraka 'De Geheime Leer van Soenan Bonang (Soeloek Woedjil)', Djawa, 18e Jaargang, 1938, hlm. 145-181. Di dalam Suluk Wujil Sunan Bonang disebut Ratu Wahdat. Selain itu juga mendapat beberapa julukan seperti sang jati wênang, sang adi gusti, sang mahamuni.

6. Berarti 'orang yang melakukan selibat (tidak beristri)'.

7. Cf. sadrăsa (6 rasa), yaitu amla (kecut), lawạ̣a (asin), kaţuka (pedas), kasaya (hambar), tikta (pahit) dan madhura (manis).

8. Pembalikan itu sudah dimulai sejak di India. Kronogram dari Nepal berbunyi Nepale samwate asmin kāya giri munibhih (tahun Nepal kăya giri munibhih) misalnya melambangkan angka 8 (kāya = badan), 7 (giri = gunung) dan 7 (munibhih $=$ pendeta $)$. Dengan demikian apabila dibalik menjadi 778 tahun Nepal. Demikian pula kronogram dari daerah Benggala berbunyi netra Rāma yuga candra melambangkan angka 3 (netra = mata), $3(\mathbf{R a ̄ m a}=$ nama pahlawan Rāma $), 2($ yuga $=$ pikulan, yugala (?) = pasangan, suami-istri) dan 1 (candra $=$ bulan). Apabila dibalik menjadi 1233. Yang menarik perhatian perkataan netra (mata) bukannya bernilai 2 seperti kronogram di Indonesia, melainkan 3. Hal ini berhubungan dengan dewa Siwa yang bermata tiga (Trinetra). Mata ketiga terletak di kening (dahi) dan digunakan untuk membakar musuh-musuhnya.

Lihat Soetjipto Wirjosoeparto 'The Significance of the Chronograms (Tjandra-Sengkala) for the Interpretation of the History of Indonesia, di dalam majalah Journal of the Oriental Society of Australia, Vol. 8, Nos. 1 \& 2, 1971, hlm. $96-112$.

9. Lihat tabel Dr. Pigeaud di dalam bukunya 'Javaans - Nederlands Handwoordenboek', hlm. IX - XI. 
10. Nisan disebut maesan, maejan atau sêkaran di dalam bahasa Jawa Baru. Di dalam makalah Sdr. Lukman Nurhakim berjudul 'Hasil Penelitian Makam-Makam Kuno di Daerah Bintan' (REHPA, Cisarua, 8-13 Maret, 1982) diuraikan arti-kata maesan, antara lain pendapat Damais yang menghubungkannya dengan mahisa (kerbau). Karena maesan (paes $=$ hias) juga disebut sêkaran (sêkar = bunga), maka nisan pada hemat saya juga berhubungan dengan tradisi sejak jaman purba, yaitu pembuatan boneka lambang orang yang telah meninggal dunia. Boneka lambang orang mati itu disebut sanghyang puspasaríra pada jaman Majapahit dan berarti 'yang mulia tubuh bunga'. Masyarakat Bali sampai sekarang masih mengenal istilah puspasarira dan sêkah (sekar = bunga) yang kemudian dibakar dan abunya dilarut atau dihanyutkan ke dalam sungai (lautan). Juga tradisi Kalang Obong di Jawa pada waktu nyewu (menyerbu hari orang meninggal) disertai pembuatan boneka lambang si mendiang yang disebut puspa dan kemudian dibakar. Selanjutnya masyarakat Tengger sewaktu menyelenggarakan slametan êntas-êntas juga membuat boneka yang disebut bespa (puspa). Karena itulah saya menduga bahwa sêkaran (maesan) juga berhubungan dengan pengertian puspa (sê$\mathbf{k a r}=$ bunga) tersebut di atas, meskipun kemudian beberapa sekaran juga dihias dengan motif bunga (flower-motif). Lihat selanjutnya M.M Sukarto 'Topeng Sang Hyang Puspaqarira (?)', majalah Sana Budaja, No. 9, Desember 1960, hlm 399 - 405, Marghani Hs 'Tradisi Obong Suku Kalang Dan Beberapa Aspeknya', majalah dinding IKIP Sanata Dharma, Yogyakarta, th. 1982, T.M. Rita Istari 'Upacara Sraddha Dan Kaitannya Dengan Upacara Kematian Lainnya Pada Masyarakat Indonesia', Skripsi tingkat Sarjana Muda Jurusan Arkeologi, Fak. Sastra dan Kebudayaan UGM, Yogyakarta, th. 1982.

11. Nama Saramênggala berarti 'panah utama', tetapi Suramenggala 'pimpinan utama yang berani'.

12. Bentuk nisan di Indonesia memang bermacam-macam. Di pulau Sumbawa dan Lombok terdapat nisan yang berbentuk menyerupai menhir (batu tegak). Di Jawa nisan kerapkali menyerupai gunungan wayang (istilah gunongan juga terdapat di Aceh dan Madura).

13. Cf. pêdanda Sakti Bahu Rawuh atau Pangeran Sangupati yang membuat kolam Surañadi di Lombok hanya menggunakan tongkatnya. Sangupati menancapkan tongkatnya empat kali di dalam tanah dan kemudian keluar air masing-masing disebut Tirta, Perlukatan, Pabersian dan Pangêntas. Baca selanjutnya F.D.K. Bosch 'Guru, Trident and Spring', di dalam Selected Studies in Indonesian Archaeology, Translation Series 5, The Hague 1961, hlm. $155-170$.

14. Andaikata yang dimaksud tahun Masehi maka prasasti itu sampai sekarang (1982) sudah berumur 221 tahun. Tetapi apabila tahun Jawa sampai sekarang baru berumur 149 tahun. 
15. Nama Sumannasa mengingatkan kita kepada kitab Sumanasāntaka yang berarti 'mati karena kembang' (sumanasa = nama bunga, antaka = mati), yaitu ketika dewi Indumati (bidadari Harini) dijatuhi bunga oleh Narada sehingga meninggal dan kembali ke sorga. Lihat Poer batjaraka 'Kapustakan Djawi', Penerbit Djambatan, 1952, hlm. 18-20.

16. Menurut etimologi rakyat (jarwa dosok) perkataan Watu Tiban itulah kemudian berubah menjadi nama kota Tuban. Lih. catatan no. 2 .

17. Karangan tentang gua Suci masih dalam persiapan.

$* * * *$

\section{Kepustakaan:}

Bosch, F.D.K.

1961 : Guru, Trident and Spring, di dalam Selected Studies in Indonesian Archaeology, Translation Series 5, The Hague, 1961, hlm. $155-170$.

\section{Lukman Nurhakim}

1982 : Hasil Penelitian Makam-Makam Kuno Di Daerah Bintan, makalah pada REHPA (Rapat Evaluasi Hasil Penelitian Arkeologi) di Cisarua, tanggal 8-13 Maret 1982.

Marghani Hs

1982 : Tradisi Obong Suku Kalang Dan Beberapa Aspeknya, majalah dinding IKIP Sanata Dharma, Yogyakarta, 1982.

Poerbatjaraka, R. Ng.

1938 : De Geheime Leer van Soenan Bonang (Soeloek Woedjil), majalah Djawa, 18e Jaargang, 1938, hlm. 145 - 181.

Pigeaud, Th

1938 : Javaans - Nederlands Handwoordenboek, penerbit J.B. Wolters Uitgevers-Maatschappy N.V., Groningen, Batavia, 1938.

Rita Istari, T.M.

1982 : Upacara Sraddha Dan Kaitannya Dengan Upacara Kematian Lainnya Pada Masyarakat Indonesia, skripsi Sarjana Muda Jurusan Arkeologi, Fak. Sastra dan Kebudayaan UGM, Yogyakarta, th. 1982.

Soebardi, S

1975 : The Book of Cabolek, Bibliotheca Indonesica 10, The Hague, Martinus Nijhoff, 1975.

Soetjipto Wiryosoeparto, R.M.

1971 : The Significance of the Chron grams (Tjandra-Sengkala) for the Interpretation of the History of Indonesia, majalah Journal of the Oriental Society of Australia, Vol. 8, Nos. 1 \& 2, 1971 , hlm. $96-122$. 
Sukarto, M.M.

1960 : Topeng Sang Hyang Puspąarira (?), majalah Sana Budaja, No. 9, Desember 1960, hlm. $399-405$.

1975 : Makam Islam Purba Selaparang, di dalam Aneka Purbakala No. 6 - 7, th. 1974 - 1975, Kantor Cabang II LPPN (Lembaga Purbakala dan Peninggalan Nasional, Gianyar, Bali.

1980 : Sedikit Tentang Nama Kota Tuban Dan Lamongan, makalah pada Kegiatan Ilmiah Dalam Rangka Sumpah Pemuda Dan Lustrum VI Fakultas Sastra Dan Kebudayaan Universitas Gadjah Mada Yogyakarta, tanggal $24-25$ Oktober 1980.

Stutterheim, W.F.

1937 : Een Inscriptie van Lombok, di dalam majalah Djawa, 17e Jaargang, 1937, hlm. $309-310$.

Umiati Rochmat, Ny.

1980 : Sekitar Tarikh Pada Gapura Makam Sunan Bonang, paper pada Pertemuan Ilmiah Arkeologi II, Jakarta.

SINGKATAN.

$\mathrm{AD}=$ Anno Domini (Tarikh Masehi).

$\mathrm{AH}=$ Anno Hijrae (tarikh Hijriah),

$\mathrm{AJ}=$ Anno Javanico (tarikh Jawa).

FAKSIMIL BEBERAPA BUAH PRASASTI DARI TUBAN.

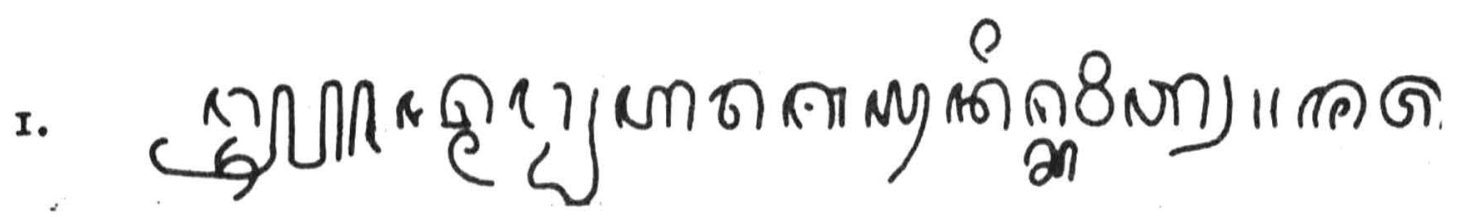

Alas dinding makam Sunan Bonang.

(//janma wyahana kayuning sawit jagat)

II.

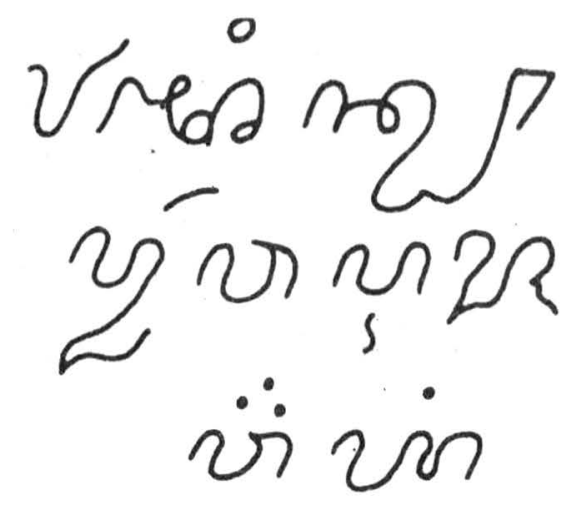

Non man

hompleks makam Rangyalawe.

(baginda purwareja waha (wafat) 1798) 


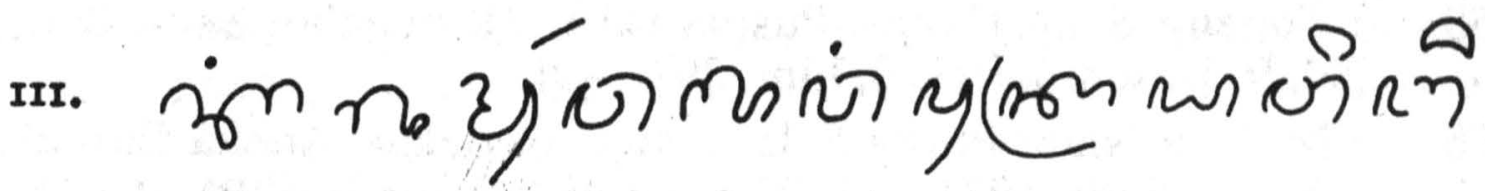

Pintu makam Seh Bejagung.

(kang hamurwa lawang pu krayatingi)

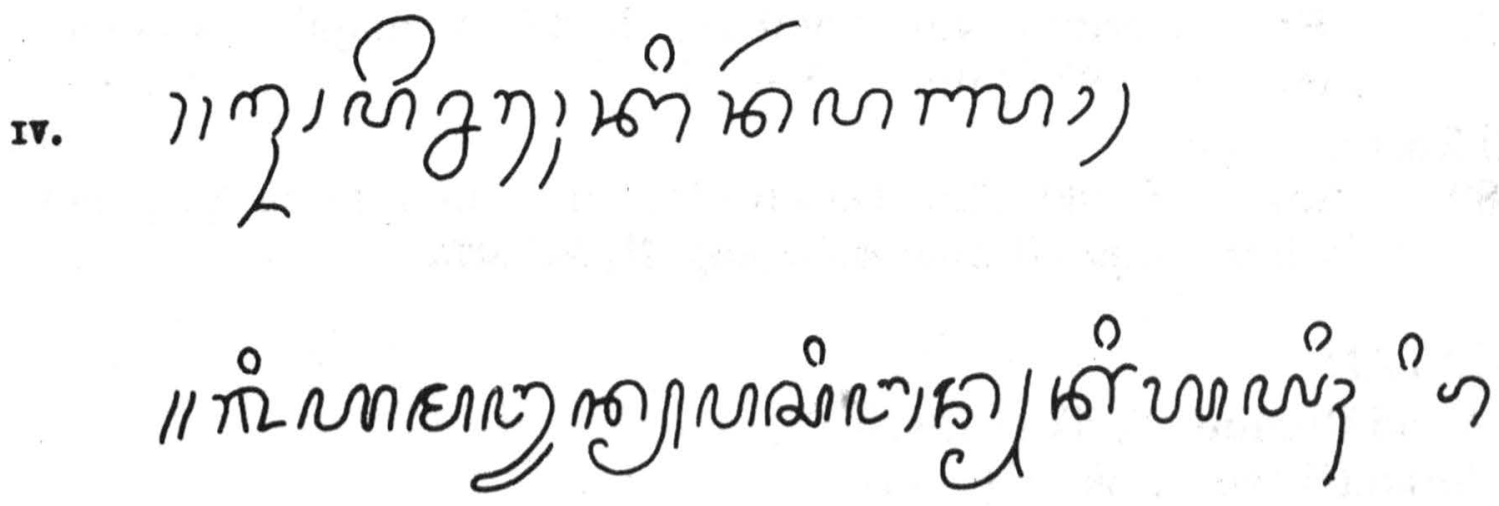

Makam Seh Ibrahim Asmara.

(//jung pecah kinarya rana (lawang)

$/ /$ kang hamangun pasiban kiyahih ... i ...).

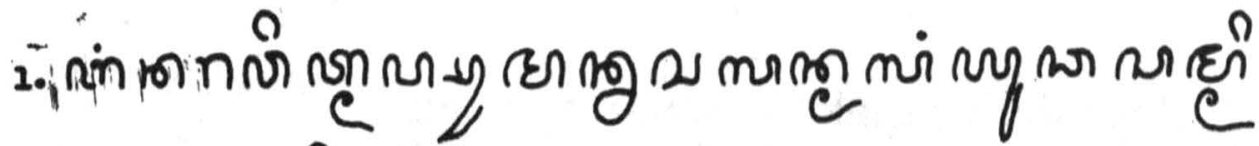

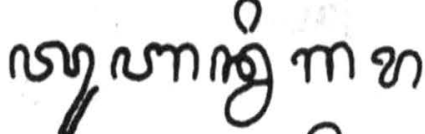

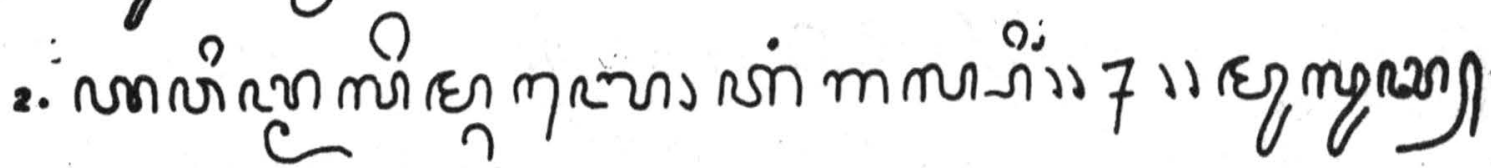

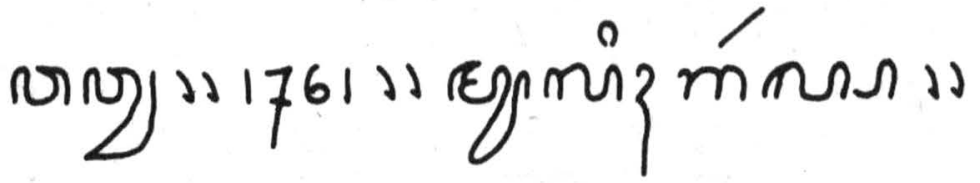

\section{Gua Gembul}

1. bangdara (hangnarawit) mas sumannasa lan malangyuda sammi tuban negara

2. hawit malem rebo tanggal ping. 7. mulut wawu. 1761. mulih ....) 